\title{
PENGARUH PEMBERIAN PUPUK ORGANIK M-DEXT TERHADAP PERTUMBUHAN TANAMAN PALAHLAR (Dipterocarpus spp.) DI WILAYAH PERUM PERHUTANI BKPH JASINGA, KPH BOGOR (Effect of M-Dext Organic Fertilizer on The Growth of Palahlar (Dipterocarpus spp.) in Perum Perhutani Forest Area, BKPH Jasinga, KPH Bogor)*
}

\author{
Oleh/By: \\ Istomo $^{1}$, Sri Wilarso ${ }^{1}$, dan/and Haris Arifiyanto Hidayat ${ }^{2}$ \\ ${ }^{1}$ Departemen Silvikultur, Fakultas Kehutanan Institut Pertanian Bogor \\ Jl. Lingkar Akademik kampus IPB Darmaga Po. Box 168 Bogor 16680 \\ Telp.+62-251-626806, Fax+62-251-626886 e-mail ecology@ipb.ac.id \\ ${ }^{2}$ Alumnus Fakultas Kehutanan Institut Pertanian Bogor \\ *Diterima : 28 September 2009; Disetujui : 23 November 2009
}

\begin{abstract}
Indeks
ABSTRACT

An effort to overcome and avoid the extinction threat of a high value tree species palahlar (Dipterocarpus spp.) in West Java is by planting these species. To support the success of planting, an important maintenance needed is a fertilizer application. The objectives of this study was to determine the effect of M-dext organic fertilizer application on the growth of palahlar (Dipterocarpus retusus Bl. and D. hasseltii Bl.). This research was conducted in a planting block of palahlar located in BKPH (Forest Sub-District) Jasinga, KPH (Forest District) Bogor, with the area of 3.5 ha. A completely randomized design with two factorials was used. The first was spacing ( $5 \mathrm{~m} \times 5 \mathrm{~m}$ and $3 \mathrm{~m} \times 3 \mathrm{~m}$ ) and the second one was M-Dext organic fertilizer application (0.0, 1.0, and $2.5 \mathrm{ml} / \mathrm{plant})$. The plant growth respond was measured six months after fertilizer application. Research results showed that treatment combination of spacing and M-Dext application gave highly significant effect on the height and diameter growths of and the height growth only of D. hasseltii. Combination of $3 \mathrm{~m} \times 3 \mathrm{~m}$ spacing and M-Dext of $1.0 \mathrm{ml} / \mathrm{plant}$ gave the best results on the height and diameter growths i.e. $2.33 \mathrm{~cm} /$ month and $0.03 \mathrm{~cm} /$ month respectively for D. retusus, and $2.31 \mathrm{~cm} / \mathrm{month}$ and $0.06 \mathrm{~cm} /$ month respectively for $\mathrm{D}$. hasseltii.
\end{abstract}

Keywords: Dipterocarpus hasseltii Bl., D. retusus Bl., organic fertilizer, spacing, height and diameter growth

\begin{abstract}
ABSTRAK
Salah satu upaya yang bisa dilakukan untuk mengatasi dan mencegah punahnya jenis pohon bernilai tinggi palahlar (Dipterocarpus spp.) di Jawa Barat adalah dengan penanaman. Dalam menunjang keberhasilan penanaman salah satu kegiatan pemeliharaan tanaman yang penting adalah pemupukan. Tujuan penelitian adalah untuk mengkaji pengaruh pemberian pupuk organik $M$-dext terhadap respon pertumbuhan anakan palahlar (Dipterocarpus retusus Bl. dan D. hasseltii Bl.). Penelitian dilakukan pada blok penanaman palahlar di wilayah BKPH Jasinga, KPH Bogor seluas 3,5 ha. Rancangan penelitian menggunakan rancangan acak lengkap dalam percobaan faktorial dengan dua perlakuan yaitu jarak tanam (5 m x 5 m dan $3 \mathrm{~m}$ x $3 \mathrm{~m}$ ) dan pemberian pupuk organik $M$-Dext $(0,0 ; 1,0$; dan $2,5 \mathrm{ml} /$ tanaman). Waktu yang diperlukan untuk mengukur respon pertumbuhan tanaman setelah pemupukan adalah enam bulan. Hasil penelitian menunjukkan bahwa kombinasi perlakuan jarak tanam $3 \mathrm{~m}$ x $3 \mathrm{~m}$ dengan dosis pupuk satu ml/tanaman memberikan pengaruh sangat nyata terhadap pertumbuhan tinggi dan diameter untuk $D$. hasseltii masing-masing sebesar 2,31 $\mathrm{cm} /$ bulan dan 0,06 cm/bulan dan untuk D. restusus masing-masing 2,33 cm/bulan dan 0,03 cm/bulan.
\end{abstract}

Kata kunci: Dipterocarpus hasseltii Bl., D. retusus Bl., pupuk organik, jarak tanam, pertumbuhan tinggi dan diameter 


\section{PENDAHULUAN}

Marga Dipterocarpus terdiri atas 70 jenis, terdapat di Kalimantan 41 jenis dan empat jenis di antaranya ditemukan di Jawa. Marga Dipterocarpus yang ditemukan di Pulau Jawa, yaitu Dipterocarpus hasseltii Bl., Dipterocarpus gracilis Bl., Dipterocarpus retusus Bl., dan Dipterocarpus littoralis Bl. (Newman et al., 1999). Di Jawa Barat jenis-jenis pohon dari marga Dipterocarpus atau keruing dikenal dengan nama palahlar.

Menurut Alrasyid (1999) beberapa jenis pohon bernilai tinggi di Jawa Barat saat ini yang sulit ditemukan adalah $D$. retusus (palahlar gunung) dan D. hasseltii (palahlar). Kedua jenis pohon dari marga Dipterocarpus ini merupakan kayu yang bernilai ekonomis tinggi yang termasuk dalam kelas awet III dan kelas kuat I-II. Faktor lain selain perambahan hutan dan penebangan liar yang menyebabkan terancam punahnya dua jenis pohon ini adalah karena masa berbuahnya yang tidak tentu dan cenderung lama, selain itu karena sifat bijinya yang mempunyai daya hidup yang pendek sehingga tidak dapat disimpan lama, juga menjadi penyebab sulitnya pengembangan dan pembiakan kedua jenis pohon ini, sehingga perlu penanganan yang khusus dan cepat.

Salah satu upaya yang bisa dilakukan untuk mengatasi dan mencegah punahnya jenis-jenis pohon itu adalah dengan penanaman. Penanaman dapat dilakukan dengan bibit yang berasal dari biji yang telah disemaikan terlebih dahulu ataupun menggunakan bibit yang berasal dari cabutan yang kemudian dikembangkan di persemaian.

Istomo et al. (2004) telah melakukan penanaman dua jenis palahlar yaitu $D$. hasseltii dan $D$. retusus di kawasan Perum Perhutani Kesatuan Pemangkuan Hutan (KPH) Bogor dan KPH Banten pada 10 blok penanaman seluas kurang-lebih 5 ha. Bibit $D$. hasseltii berasal dari Cagar Alam Leuweung Sancang, Garut, dan bibit $D$. retusus berasal dari Hutan
Lindung Gunung Cakrabuana, Sumedang, keduanya di wilayah Jawa Barat. Bibit yang ditanam berasal dari anakan alam (cabutan dan puteran) serta dari persemaian biji. Penanaman menggunakan dua macam jarak tanam yaitu $3 \mathrm{~m} \mathrm{x} 3 \mathrm{~m}$ dan $5 \mathrm{~m}$ x $5 \mathrm{~m}$. Untuk menjamin pertumbuhan tanaman diperlukan pemeliharaan berupa penyiangan gulma dan pemupukan.

Salah satu pupuk yang digunakan dalam pemeliharaan adalah pupuk organik M-Dext. Oleh karena itu dalam penelitian ini dilakukan kajian penggunaan pupuk organik $M$-Dext yang merupakan pupuk organik yang mampu meningkatkan pertumbuhan tanaman dan tidak mengandung polutan, sehingga aman bagi lingkungan. Pupuk organik M-Dext ini di samping mempengaruhi tanaman secara langsung juga dapat meningkatkan keanekaragaman mikroorganisme tanah lokal, menyokong kehidupan organisme dalam tanah miskin, mempercepat pelepasan unsur hara serta menyeimbangkan unsur-unsur tanah dan $\mathrm{pH}$ tanah (Hadi, 2001a). Dengan pemberian pupuk organik $M$-Dext ini diharapkan dapat membantu pertumbuhan tanaman dan menghasilkan tanaman dengan kualitas yang baik.

Tujuan dari penelitian ini adalah untuk mengkaji pengaruh jarak tanam dan pemberian pupuk organik $M$-Dext terhadap respon pertumbuhan anakan palahlar gunung (D. retusus) dan palahlar (D. hasseltii) di areal penanaman Resor Pemangkuan Hutan (RPH) Cigudeg, Bagian Kesatuan Pemangkuan Hutan (BKPH) Jasinga, KPH Bogor.

\section{METODE PENELITIAN}

\section{A. Waktu dan Lokasi}

Penelitian ini mulai Desember 2004 sampai bulan Agustus 2005 di kawasan hutan PT Perhutani yang termasuk wilayah kerja RPH Cigudeg, BKPH Jasinga, 
KPH Bogor, Perhutani Unit III Jawa Barat.

\section{B. Bahan dan Alat}

Bahan yang digunakan dalam penelitian ini adalah tanaman palahlar gunung (D. retusus) dan palahlar (D. hasseltii) berumur dua tahun, serta pupuk organik yaitu $M$-Dext.

Alat-alat yang digunakan dalam penelitian ini meliputi kompas brunton, altimeter, sunto clinometer, parang, tambang, patok, cangkul, label pohon, gelas ukur, ajir, kaliper, penggaris, serta alat tulis.

\section{Prosedur Pelaksanaan Penelitian}

Tahap-tahap yang dilakukan dalam pelaksanaan penelitian ini meliputi:

\section{Pemberian Pupuk}

Pemberian pupuk organik $M$-Dext dengan dosis 0,$0 ; 1,0$; dan 2,5 ml/pohon untuk setiap tanaman yang mendapat perlakuan. Pupuk diberikan dengan cara penyiraman secara langsung di sekitar tanaman setelah dicampur dengan air sebanyak 200 ml per tanaman.

\section{Pemeliharaan}

Pemeliharaan dilakukan setiap tiga bulan sekali dengan membersihkan semak yang ada di sekitar tanaman dan jalur pengamatan/pemeriksaan.

\section{Pengamatan}

Parameter yang diamati dalam penelitian ini adalah pertambahan pertumbuhan tinggi dan diameter per jenis tanaman dan per perlakuan dengan interval pengamatan tiga bulan sekali sejak dilakukan pengukuran awal dan pemupukan selama enam bulan.

\section{Rancangan Percobaan dan Analisis Data}

Rancangan percobaan yang digunakan dalam penelitian ini adalah rancangan acak lengkap dalam percobaan faktorial yang terdiri dari dua faktor.

Faktor pertama (faktor A) adalah jarak tanam yang terdiri atas dua taraf, yaitu:

$\mathrm{J}_{1}$ : jarak tanam $5 \mathrm{~m} \times 5 \mathrm{~m}$

$\mathrm{J}_{2}$ : jarak tanam $3 \mathrm{~m} \times 3 \mathrm{~m}$

Faktor kedua (faktor B) adalah penggunaan pupuk organik $M$-Dext yang terdiri dari tiga taraf, yaitu:

$\mathrm{N}_{0}$ : dosis $0,0 \mathrm{ml} /$ tanaman

$\mathrm{N}_{1}$ : dosis $1,0 \mathrm{ml} /$ tanaman

$\mathrm{N}_{2}$ : dosis $2,5 \mathrm{ml} /$ tanaman

Dengan demikian terdapat enam kombinasi perlakuan yang selanjutnya dibuat dalam lima ulangan dalam bentuk blok, sehingga menjadi 30 satuan percobaan (2 $\mathrm{x} 3 \times 5$ ). Satu ulangan atau satu satuan percobaan dalam penelitian ini adalah satu blok tanaman dalam wilayah seluas (25 x 50) $\mathrm{m}^{2}$ atau setara dengan 0,125 ha yang berisi 28 tanaman.

Model rancangan yang digunakan adalah sebagai berikut:

Yijk $=\mu+\alpha_{i}+\beta_{j}+(\alpha \beta)_{i j}+\rho_{k}+\varepsilon_{i j k}$

Keterangan:

$\mathrm{Y}_{\mathrm{ijk}} \quad$ : Nilai pengamatan pada faktor A taraf kei dan faktor B taraf ke-j dan kelompok ke-k.

$\mu \quad$ : Nilai rataan umum

$\alpha_{I} \quad$ : Pengaruh utama faktor A taraf ke-i

$\beta_{\mathrm{j}} \quad$ : Pengaruh utama faktor B taraf ke-j

$(\alpha \beta)_{\mathrm{ij}} \quad$ : Interaksi faktor A dan faktor B

$\varepsilon_{\mathrm{ijk}} \quad$ : Pengaruh acak faktor A dan B serta kelompok k

i $\quad: 1,2$

j $: 1,2,3$

Selanjutnya dilakukan analisis data dengan uji Anova. Hipotesis yang diuji adalah:

$\mathrm{H}_{0}$ : Perlakuan tidak berpengaruh nyata terhadap pertumbuhan anakan palahlar

$\mathrm{H}_{1}$ : Perlakuan berpengaruh nyata terhadap pertumbuhan anakan palahlar.

Sedangkan kriteria pengambilan keputusan dari hipotesis yang diuji adalah:

F hitung $<\mathrm{F}$ tabel, terima $\mathrm{H}_{0}$ $\mathrm{F}$ hitung $>\mathrm{F}$ tabel, terima $\mathrm{H}_{1}$

Jika uji $F$ nyata, maka dilanjutkan dengan uji pembanding linier antar 
perlakuan (kontras) (Mattjik dan Sumertajaya, 2000; Steel and Torrie, 1980). Analisis data hasil pengamatan dari percobaan ini dilakukan dengan menggunakan program aplikasi statistik SAS.

\section{HASIL DAN PEMBAHASAN}

\section{A. Hasil}

\section{Jenis Dipterocarpus hasseltii Bl.}

\section{a. Pertumbuhan Tinggi}

Rekapitulasi pertumbuhan tinggi selama tiga kali pengukuran dengan enam kombinasi perlakuan dapat dilihat pada Tabel 1.

Berdasarkan Tabel 1 dapat diketahui bahwa perlakuan yang memberikan respon terhadap pertumbuhan tinggi tanaman $D$. hasseltii terbesar terdapat pada perlakuan jarak tanam $3 \mathrm{~m}$ x 3 m dengan dosis pupuk 1,0 ml/pohon $\left(\mathrm{J}_{2} \mathrm{~N}_{1}\right)$ sebesar $13,84 \mathrm{~cm}$ selama enam bulan pengamatan. Sedangkan respon terendah terdapat pada perlakuan jarak tanam $5 \mathrm{~m}$ x $5 \mathrm{~m}$ dengan dosis pupuk 2,5 ml/pohon $\left(\mathrm{J}_{1} \mathrm{~N}_{2}\right)$ sebesar 10,85 cm.

Dari Gambar 1 tampak bahwa pada selang pengukuran pertama terjadi pertambahan tinggi rata-rata terbaik pada perlakuan jarak tanam $3 \mathrm{~m}$ x $3 \mathrm{~m}$ dengan dosis pupuk $0,0 \mathrm{ml} /$ pohon (kontrol) sebesar $8,31 \mathrm{~cm}$, dan pada selang pengukuran kedua terjadi pertambahan tinggi rata-rata terbesar pada perlakuan jarak tanam $3 \mathrm{~m}$ x $3 \mathrm{~m}$ dengan dosis pupuk $1 \mathrm{ml} /$ pohon $\left(\mathrm{J}_{2} \mathrm{~N}_{1}\right)$ sebesar $6,25 \mathrm{~cm}$.

Hasil sidik ragam pada Tabel 2 menunjukkan bahwa adanya kombinasi perlakuan jarak tanam dan pemberian pupuk organik $M$-Dext memberikan pengaruh yang nyata pada tingkat kepercayaan 95\% terhadap respon pertumbuhan tinggi tanaman $D$ hasseltii selama enam bulan dilakukan pengamatan (Tabel 2).

Dari hasil uji lanjut pembanding linier antar perlakuan (kontras) pada Tabel 3 dapat diketahui bahwa perlakuan jarak tanam $5 \mathrm{~m} \mathrm{x} 5 \mathrm{~m}$ dengan dosis pupuk $1 \mathrm{ml} /$ pohon memberikan respon terbesar pada pertumbuhan tinggi tanaman sebesar 13,85 cm (Tabel 3).

Tabel (Table) 1. Pertumbuhan tinggi rata-rata $D$. hasseltii pada setiap perlakuan selama enam bulan pengamatan (Average of height growth rate at each treatment during six month observation)

\begin{tabular}{|c|c|c|c|c|c|}
\hline $\begin{array}{l}\text { Perlakuan } \\
\text { (Treatment) }\end{array}$ & $\begin{array}{c}\text { Ulangan } \\
\text { (Replication) }\end{array}$ & $\begin{array}{l}\text { Pertumbuhan tinggi } \\
\text { (Height growth) } \\
(\mathrm{cm})\end{array}$ & $\begin{array}{l}\text { Perlakuan } \\
\text { (Treatment) }\end{array}$ & $\begin{array}{c}\text { Ulangan } \\
\text { (Replication) }\end{array}$ & $\begin{array}{l}\text { Pertumbuhan tinggi } \\
\text { (Height growth) } \\
(\mathrm{cm})\end{array}$ \\
\hline \multirow[t]{5}{*}{$\mathrm{J}_{1} \mathrm{~N}_{0}$} & 1 & 13,94 & \multirow[t]{5}{*}{$\mathrm{J}_{2} \mathrm{~N}_{0}$} & 1 & 13,94 \\
\hline & 2 & 12,00 & & 2 & 17,36 \\
\hline & 3 & 11,94 & & 3 & 16,31 \\
\hline & 4 & 9,50 & & 4 & 12,69 \\
\hline & 5 & 8,50 & & 5 & 8,38 \\
\hline \multicolumn{2}{|c|}{ Rata-rata (Average) } & 11,18 & \multicolumn{2}{|c|}{ Rata-rata (Average) } & 13,74 \\
\hline \multirow[t]{5}{*}{$\mathrm{J}_{1} \mathrm{~N}_{1}$} & 1 & 19,50 & \multirow[t]{5}{*}{$\mathrm{J}_{2} \mathrm{~N}_{1}$} & 1 & 12,56 \\
\hline & 2 & 13,56 & & 2 & 15,00 \\
\hline & 3 & 19,69 & & 3 & 12,56 \\
\hline & 4 & 8,94 & & 4 & 15,88 \\
\hline & 5 & 3,75 & & 5 & 13,19 \\
\hline \multicolumn{2}{|c|}{ Rata-rata (Average) } & 13,09 & \multicolumn{2}{|c|}{ Rata-rata (Average) } & 13,84 \\
\hline \multirow[t]{5}{*}{$\mathrm{J}_{1} \mathrm{~N}_{2}$} & 1 & 14,00 & \multirow[t]{5}{*}{$\mathrm{J}_{2} \mathrm{~N}_{2}$} & 1 & 10,38 \\
\hline & 2 & 12,94 & & 2 & 15,94 \\
\hline & 3 & 11,25 & & 3 & 10,94 \\
\hline & 4 & 8,25 & & 4 & 11,38 \\
\hline & 5 & 7,81 & & 5 & 7,75 \\
\hline \multicolumn{2}{|c|}{ Rata-rata (Average) } & 10,85 & \multicolumn{2}{|c|}{ Rata-rata (Average) } & 11,28 \\
\hline
\end{tabular}




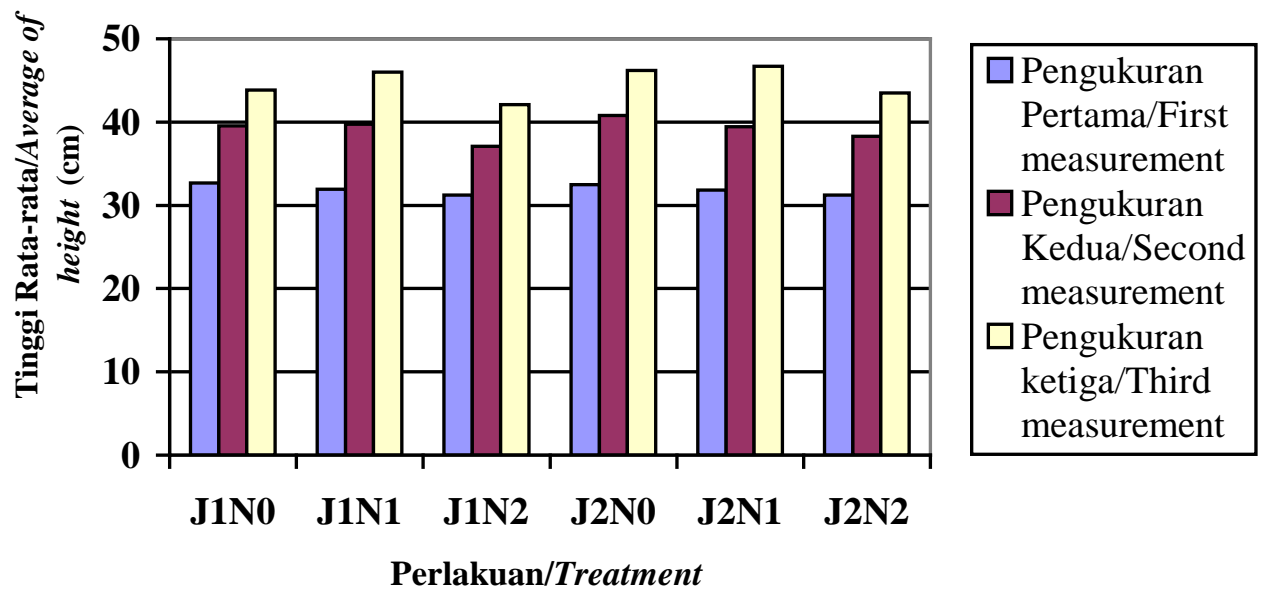

Gambar (Figure) 1. Pengaruh berbagai kombinasi perlakuan terhadap pertumbuhan tinggi tanaman $D$. haseltii (Effect of treatment combination on plant height growth)

Tabel (Table) 2. Sidik ragam pertambahan tinggi tanaman D. hasseltii (Analysis of variance for height growth rate of $\mathrm{D}$. hasseltii)

\begin{tabular}{lccccc}
\hline Sumber keragaman (Source of variation) & $\mathrm{Db}(d f)$ & $\mathrm{JK}(S S)$ & $\mathrm{KT}(M S)$ & $\mathrm{F}$ & $\mathrm{P}$ value \\
\hline Perlakuan (Treatment) & 9 & 171,3580 & 19,0397 & $2,73^{*}$ & 0,0293 \\
Galat (Error) & 20 & 139,3087 & 6,9654 & & \\
Total & 29 & 310,6667 & & & \\
\hline
\end{tabular}

*Nyata pada taraf (Significant at level) $90 \%$

Tabel (Table) 3. Hasil uji lanjut pembanding linier antar perlakuan terhadap variabel tinggi tanaman $D$. hasseltii (Result of linear test inter treatment for D. hasseltii height growth)

\begin{tabular}{ccc}
\hline $\begin{array}{c}\text { Dosis pupuk } \\
\text { (Fertilizer dosage) }(\mathrm{ml} / \text { pohon })\end{array}$ & $\begin{array}{c}\text { Jarak tanam } \\
(\text { Spacing })(\mathrm{m})\end{array}$ & $\begin{array}{c}\text { Rata-rata pertumbuhan tinggi } \\
\text { (Average of height growth })(\mathrm{cm})\end{array}$ \\
\hline 0 & 3 & 13,74 \\
0 & 5 & 11,17 \\
1 & 3 & 13,84 \\
1 & 5 & 13,85 \\
2,5 & 3 & 11,79 \\
2,5 & 5 & 10,85 \\
\hline
\end{tabular}

\section{b. Pertumbuhan Diameter}

Rekapitulasi pertumbuhan diameter selama tiga kali pengukuran dengan enam kombinasi perlakuan dapat dilihat pada Tabel 4.

Pada Tabel 4 tampak bahwa perlakuan jarak tanam $3 \mathrm{~m} \times 3 \mathrm{~m}$ dengan dosis pupuk $1 \mathrm{ml} /$ pohon $\left(\mathrm{J}_{2} \mathrm{~N}_{1}\right)$ memberikan respon pertumbuhan diameter yang terbesar yaitu sebesar 0,35 cm dibanding dengan perlakuan yang lain. Dari hasil ini juga tampak bahwa pertumbuhan kontrol $\left(\mathrm{J}_{1} \mathrm{~N}_{0}\right.$ dan $\left.\mathrm{J}_{2} \mathrm{~N}_{0}\right)$ juga menunjukkan hasil yang lebih baik pada pertumbuhan dia- meter dibanding perlakuan pemberian pupuk organik pada dosis 2,5 ml/pohon, baik pada jarak tanam $3 \mathrm{~m} \times 3 \mathrm{~m}$ maupun pada jarak tanam $5 \mathrm{~m}$ x $5 \mathrm{~m}$.

Pada Gambar 2 dapat dilihat bahwa pada perlakuan jarak tanam $3 \mathrm{~m} \times 3 \mathrm{~m}$ dengan dosis pupuk $1 \mathrm{ml} /$ pohon $\left(\mathrm{J}_{2} \mathrm{~N}_{1}\right)$ pada selang pengukuran pertama memberikan respon pertumbuhan terbesar sebesar $0,23 \mathrm{~cm}$ dan pada selang pengukuran kedua perlakuan jarak tanam $5 \mathrm{~m}$ x $5 \mathrm{~m}$ dengan dosis pupuk $1 \mathrm{ml} /$ pohon memberikan respon pertumbuhan diameter terbaik sebesar $0,15 \mathrm{~cm}$. 
Tabel (Table) 4. Pertumbuhan diameter rata-rata D. hasseltii pada setiap perlakuan selama enam bulan pengamatan (Average of height growth rate of $\mathrm{D}$. hasseltii at each treatment during six month observation)

\begin{tabular}{|c|c|c|c|c|c|}
\hline $\begin{array}{l}\text { Perlakuan } \\
\text { (Treatment) }\end{array}$ & $\begin{array}{c}\text { Ulangan } \\
\text { (Replication) }\end{array}$ & $\begin{array}{l}\text { Pertumbuhan tinggi } \\
\text { (Height growth) } \\
(\mathrm{cm})\end{array}$ & $\begin{array}{c}\text { Perlakuan } \\
\text { (Treatment) }\end{array}$ & $\begin{array}{c}\text { Ulangan } \\
\text { (Replication) }\end{array}$ & $\begin{array}{l}\text { Pertumbuhan tinggi } \\
\text { (Height growth) } \\
(\mathrm{cm})\end{array}$ \\
\hline \multirow[t]{5}{*}{$\mathrm{J}_{1} \mathrm{~N}_{0}$} & 1 & 0,29 & \multirow[t]{5}{*}{$\mathrm{J}_{2} \mathrm{~N}_{0}$} & 1 & 0,26 \\
\hline & 2 & 0,31 & & 2 & 0,34 \\
\hline & 3 & 0,39 & & 3 & 0,20 \\
\hline & 4 & 0,13 & & 4 & 0,30 \\
\hline & 5 & 0,31 & & 5 & 0,23 \\
\hline \multicolumn{2}{|c|}{ Rata-rata (Average) } & 0,29 & \multicolumn{2}{|c|}{ Rata-rata (Average) } & 0,27 \\
\hline \multirow[t]{5}{*}{$\mathrm{J}_{1} \mathrm{~N}_{1}$} & 1 & 0,42 & \multirow[t]{5}{*}{$\mathrm{J}_{2} \mathrm{~N}_{1}$} & 1 & 0,24 \\
\hline & 2 & 0,25 & & 2 & 0,38 \\
\hline & 3 & 0,39 & & 3 & 0,49 \\
\hline & 4 & 0,21 & & 4 & 0,29 \\
\hline & 5 & 0,21 & & 5 & 0,33 \\
\hline \multicolumn{2}{|c|}{ Rata-rata (Average) } & 0,29 & \multicolumn{2}{|c|}{ Rata-rata (Average) } & 0,35 \\
\hline \multirow[t]{5}{*}{$\mathrm{J}_{1} \mathrm{~N}_{2}$} & 1 & 0,36 & \multirow[t]{5}{*}{$\mathrm{J}_{2} \mathrm{~N}_{2}$} & 1 & 0,27 \\
\hline & 2 & 0,30 & & 2 & 0,35 \\
\hline & 3 & 0,28 & & 3 & 0,28 \\
\hline & 4 & 0,12 & & 4 & 0,22 \\
\hline & 5 & 0,26 & & 5 & 0,18 \\
\hline \multicolumn{2}{|c|}{ Rata-rata (Average) } & 0,26 & \multicolumn{2}{|c|}{ Rata-rata (Average) } & 0,26 \\
\hline
\end{tabular}

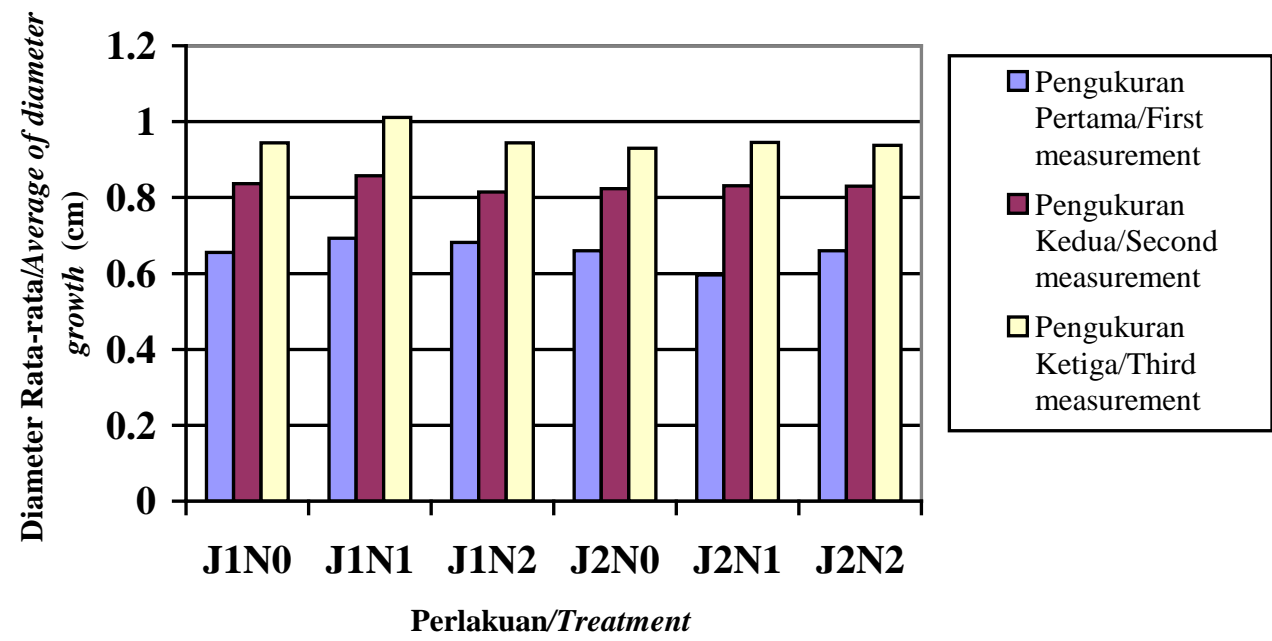

Gambar (Figure) 2. Pengaruh berbagai kombinasi perlakuan terhadap pertumbuhan diameter tanaman $D$. hasseltii (Effect of treatment combination on D. hasseltii diameter growth)

Dari hasil sidik ragam terhadap respon pertumbuhan diameter tanaman $D$. hasseltii dapat diketahui bahwa adanya perlakuan jarak tanam dan pemberian pupuk organik $M$-Dext ternyata tidak memberikan pengaruh yang nyata terhadap pertumbuhan diameter tanaman. Namun dengan melihat hasil yang didapat dari pengukuran pengamatan selama enam bulan dapat diketahui bahwa tanaman mengalami pertumbuhan yang baik (Tabel 5). 
Tabel (Table) 5. Sidik ragam pertambahan diameter tanaman D. hasseltii (Analysis of variance for diameter growth rate of $\mathrm{D}$. hasseltii)

\begin{tabular}{lccccc}
\hline Sumber keragaman (Source of variation) & $\mathrm{Db}(d f)$ & $\mathrm{JK}(S S)$ & $\mathrm{KT}(M S)$ & $\mathrm{F}$ & $\mathrm{P}$ value \\
\hline Perlakuan (Treatment) & 9 & 0,8688 & 0,0096 & $1,92^{\text {tn/ns }}$ & 0,1077 \\
Galat (Error) & 20 & 0,1005 & 0,0050 & & \\
Total & 29 & 0,1874 & & & \\
\hline
\end{tabular}

tn/ns: Tidak nyata (Not significant)

Tabel (Table) 6. Pertumbuhan tinggi rata-rata D. retusus pada setiap perlakuan selama enam bulan pengamatan (Average of height growth rate of $\mathrm{D}$. retusus at each treatment during six month observation)

\begin{tabular}{|c|c|c|c|c|c|}
\hline $\begin{array}{l}\text { Perlakuan } \\
\text { (Treatment) }\end{array}$ & $\begin{array}{c}\text { Ulangan } \\
\text { (Replication) }\end{array}$ & $\begin{array}{l}\text { Pertumbuhan tinggi } \\
\text { (Height growth) } \\
\text { (cm) }\end{array}$ & $\begin{array}{l}\text { Perlakuan } \\
\text { (Treatment) }\end{array}$ & $\begin{array}{c}\text { Ulangan } \\
\text { (Replication) }\end{array}$ & $\begin{array}{l}\text { Pertumbuhan tinggi } \\
\text { (Height growth) } \\
(\mathrm{cm})\end{array}$ \\
\hline \multirow[t]{5}{*}{$\mathrm{J}_{1} \mathrm{~N}_{0}$} & 1 & 16,06 & $\mathrm{~J}_{2} \mathrm{~N}_{0}$ & 1 & 17,63 \\
\hline & 2 & 10,81 & & 2 & 19,06 \\
\hline & 3 & 15,44 & & 3 & 9,50 \\
\hline & 4 & 5,69 & & 4 & 9,69 \\
\hline & 5 & 2,88 & & 5 & 5,50 \\
\hline \multicolumn{2}{|c|}{ Rata-rata (Average) } & 10,18 & \multicolumn{2}{|c|}{ Rata-rata (Average) } & 12,28 \\
\hline \multirow[t]{5}{*}{$\mathrm{J}_{1} \mathrm{~N}_{1}$} & 1 & 19,69 & \multirow[t]{5}{*}{$\mathrm{J}_{2} \mathrm{~N}_{1}$} & 1 & 15,75 \\
\hline & 2 & 9,06 & & 2 & 20,69 \\
\hline & 3 & 14,88 & & 3 & 13,06 \\
\hline & 4 & 8,69 & & 4 & 11,25 \\
\hline & 5 & 8,19 & & 5 & 6,88 \\
\hline \multicolumn{2}{|c|}{ Rata-rata (Average) } & 12,10 & \multicolumn{2}{|c|}{ Rata-rata (Average) } & 13,53 \\
\hline \multirow[t]{5}{*}{$\mathrm{J}_{1} \mathrm{~N}_{2}$} & 1 & 23,94 & \multirow[t]{5}{*}{$\mathrm{J}_{2} \mathrm{~N}_{2}$} & 1 & 20,19 \\
\hline & 2 & 13,56 & & 2 & 22,88 \\
\hline & 3 & 12,88 & & 3 & 11,75 \\
\hline & 4 & 7,63 & & 4 & 9,00 \\
\hline & 5 & 8,19 & & 5 & 6,88 \\
\hline \multicolumn{2}{|c|}{ Rata-rata (Average) } & 13,24 & \multicolumn{2}{|c|}{ Rata-rata (Average) } & 14,14 \\
\hline
\end{tabular}

2. Jenis Dipterocarpus retusus Bl.

\section{a. Pertumbuhan Tinggi}

Rekapitulasi pertumbuhan tinggi selama tiga kali pengukuran dengan enam kombinasi perlakuan dapat dilihat pada Tabel 6.

Dengan melihat data pertumbuhan rata-rata tinggi tanaman $D$. retusus selama enam bulan pengamatan, tampak bahwa tanaman memberikan respon pertumbuhan rata-rata tinggi terbesar pada perlakuan jarak tanam $3 \mathrm{~m}$ x $3 \mathrm{~m}$ dengan dosis pupuk 2,5 ml/pohon sebesar 14,14 cm dan pada perlakuan jarak tanam $3 \mathrm{~m}$ x 3 $\mathrm{m}$ dengan dosis pupuk $1 \mathrm{ml} /$ pohon yaitu sebesar 13,53 cm. Sedangkan respon terendah terdapat pada perlakuan jarak tanam $5 \mathrm{~m} \mathrm{x} 5 \mathrm{~m}$ dengan dosis pupuk $0 \mathrm{ml} /$ pohon (kontrol) sebesar 10,18 cm.
Pada Gambar 3 dapat dilihat bahwa antara pengukuran pertama dan pengukuran kedua terjadi pertambahan tinggi rata-rata tanaman terbesar pada perlakuan jarak tanam $3 \mathrm{~m}$ x $3 \mathrm{~m}$ dengan dosis pupuk 2,5 ml/pohon $\left(\mathrm{J}_{2} \mathrm{~N}_{2}\right)$ sebesar 10,01 $\mathrm{cm}$ dan pada selang pengukuran kedua pertambahan terbesar terdapat pada perlakuan jarak tanam $3 \mathrm{~m}$ x $3 \mathrm{~m}$ dengan dosis pupuk $0 \mathrm{ml} /$ pohon (kontrol) sebesar 5,65 cm.

Setelah dilakukan sidik ragam dari data pertambahan tinggi tanaman $D$. retusus, menunjukkan bahwa adanya kombinasi perlakuan antara jarak tanam dan pemberian pupuk organik M-Dext memberikan pengaruh yang sangat nyata terhadap pertambahan tinggi tanaman pada tingkat kepercayaan 99\% (Tabel 7). 
Pada Tabel 8 disajikan data hasil uji lanjut pembanding linier antar perlakuan. Dari tabel ini tampak bahwa kombinasi jarak tanam dan pemberian pupuk organik $M$-Dext pada tanaman $D$. retusus memberikan respon terbesar pada kombinasi perlakuan jarak tanam $3 \mathrm{~m}$ x $3 \mathrm{~m}$ dengan dosis pupk 2,5 ml/pohon dengan pertambahan tinggi selama enam bulan pengamatan sebesar $14,93 \mathrm{~cm}$.

\section{b. Pertumbuhan Diameter}

Rekapitulasi pertumbuhan diameter selama tiga kali pengukuran dengan enam kombinasi perlakuan dapat dilihat pada Tabel 9.

Berdasarkan Tabel 9 dapat diketahui bahwa tanaman memberikan respon pertumbuhan diameter terbesar pada perlakuan jarak tanam $5 \mathrm{~m} \times 5 \mathrm{~m}$ dengan dosis pupuk $0 \mathrm{ml} /$ pohon (kontrol) sebesar 0,20 $\mathrm{cm}$, kemudian tanaman dengan jarak tanam $3 \mathrm{~m} \mathrm{x} 3 \mathrm{~m}$ dan dosis pupuk $1 \mathrm{ml} /$ pohon $\left(\mathrm{J}_{2} \mathrm{~N}_{1}\right)$ memberikan respon pertumbuhan diameter terbesar kedua sebesar $0,19 \mathrm{~cm}$ dan terendah terdapat pada perlakuan jarak tanam $5 \mathrm{~m}$ x $5 \mathrm{~m}$ dengan dosis pupuk $1 \mathrm{ml} /$ pohon $\left(\mathrm{J}_{1} \mathrm{~N}_{1}\right)$ sebesar 0,16 $\mathrm{cm}$.

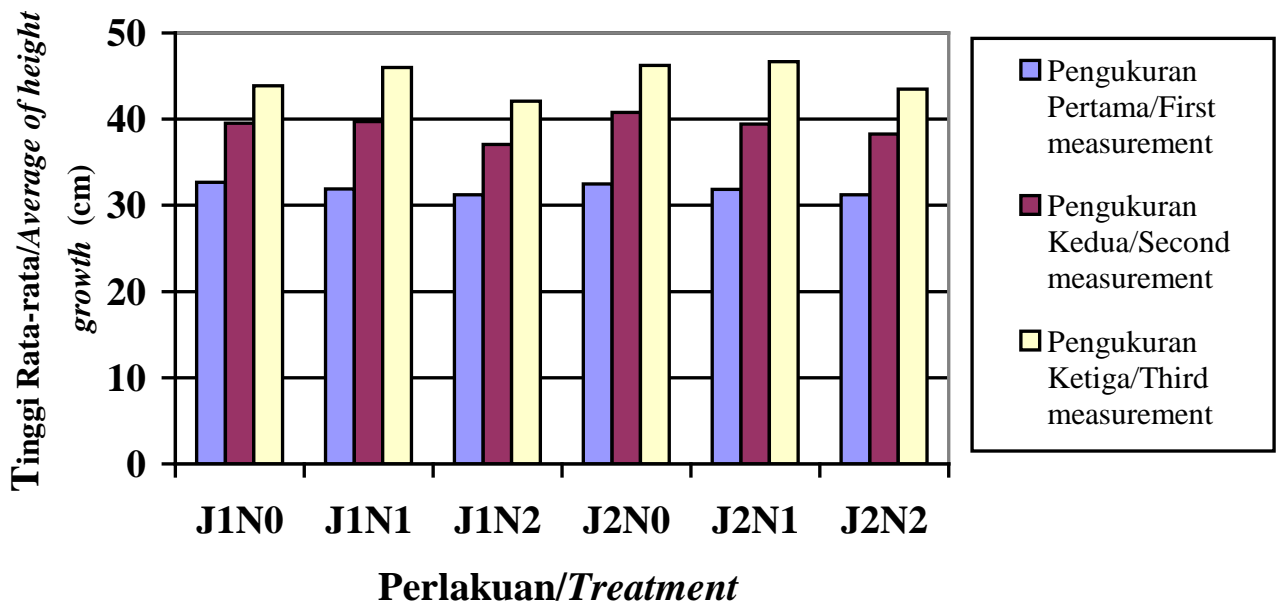

Gambar (Figure) 3. Pengaruh berbagai kombinasi perlakuan terhadap pertumbuhan tinggi tanaman $D$. retusus (Effect of treatment combination for D. retusus height growth)

Tabel (Table) 7. Sidik ragam pertambahan tinggi tanaman D. retusus (Analysis of variance for height growth rate of $\mathrm{D}$. retusus)

\begin{tabular}{lccccc}
\hline Sumber keragaman (Source of variation) & $\mathrm{db}(d f)$ & $\mathrm{JK}(S S)$ & $\mathrm{KT}(M S)$ & $\mathrm{F}$ & P value \\
\hline Perlakuan (Treatment) & 9 & 552,3746 & 61,3749 & $5,71^{* *}$ & 0,0006 \\
Galat (Error) & 20 & 215,0692 & 10,7534 & & \\
Total & 29 & 767,4439 & & & \\
\hline
\end{tabular}

** Sangat nyata pada taraf (Highly significant at level) 99\%

Tabel (Table) 8. Hasil uji lanjut pembanding linier antar perlakuan terhadap variabel tinggi tanaman $D$. retusus (Result of linear test inter treatment for D. retusus height growth)

\begin{tabular}{ccc}
\hline $\begin{array}{c}\text { Dosis pupuk } \\
\text { (Fertilizer dosage) }\end{array}(\mathrm{ml} /$ pohon $)$ & $\begin{array}{c}\text { Jarak tanam } \\
(\text { Spacing })(\mathrm{m})\end{array}$ & $\begin{array}{c}\text { Rata-rata pertumbuhan tinggi } \\
\text { (Average of height growth })(\mathrm{cm})\end{array}$ \\
\hline 0 & 3 & 12,66 \\
0 & 5 & 10,55 \\
1 & 3 & 13,98 \\
1 & 5 & 12,68 \\
2,5 & 3 & 14,93 \\
2,5 & 5 & 13,74 \\
\hline
\end{tabular}


Tabel (Table) 9. Pertumbuhan diameter rata-rata D. retusus pada setiap perlakuan selama enam bulan pengamatan (Average of diameter growth rate of D. retusus at each treatment during six month observation)

\begin{tabular}{|c|c|c|c|c|c|}
\hline $\begin{array}{l}\text { Perlakuan } \\
\text { (Treatment) }\end{array}$ & $\begin{array}{c}\text { Ulangan } \\
\text { (Replication) }\end{array}$ & $\begin{array}{l}\text { Pertumbuhan tinggi } \\
\text { (Height growth) } \\
\text { (cm) }\end{array}$ & $\begin{array}{l}\text { Perlakuan } \\
\text { (Treatment) }\end{array}$ & $\begin{array}{c}\text { Ulangan } \\
\text { (Replication) }\end{array}$ & $\begin{array}{c}\text { Pertumbuhan tinggi } \\
\text { (Height growth) } \\
\text { (cm) }\end{array}$ \\
\hline \multirow{5}{*}{$\mathrm{J}_{1} \mathrm{~N}_{0}$} & 1 & 0,43 & \multirow[t]{5}{*}{$\mathrm{J}_{2} \mathrm{~N}_{0}$} & 1 & 0,29 \\
\hline & 2 & 0,28 & & 2 & 0,31 \\
\hline & 3 & 0,18 & & 3 & 0,13 \\
\hline & 4 & 0,08 & & 4 & 0,08 \\
\hline & 5 & 0,03 & & 5 & 0,06 \\
\hline \multicolumn{2}{|c|}{ Rata-rata (Average) } & 0,20 & \multicolumn{2}{|c|}{ Rata-rata (Average) } & 0,18 \\
\hline \multirow{5}{*}{$\mathrm{J}_{1} \mathrm{~N}_{1}$} & 1 & 0,33 & \multirow{5}{*}{$\mathrm{J}_{2} \mathrm{~N}_{1}$} & 1 & 0,28 \\
\hline & 2 & 0,19 & & 2 & 0,32 \\
\hline & 3 & 0,19 & & 3 & 0,17 \\
\hline & 4 & 0,07 & & 4 & 0,11 \\
\hline & 5 & 0,01 & & 5 & 0,08 \\
\hline \multicolumn{2}{|c|}{ Rata-rata (Average) } & 0,16 & \multicolumn{2}{|c|}{ Rata-rata (Average) } & 0,19 \\
\hline \multirow[t]{5}{*}{$\mathrm{J}_{1} \mathrm{~N}_{2}$} & 1 & 0,46 & \multirow[t]{5}{*}{$\mathrm{J}_{2} \mathrm{~N}_{2}$} & 1 & 0,27 \\
\hline & 2 & 0,21 & & 2 & 0,34 \\
\hline & 3 & 0,16 & & 3 & 0,12 \\
\hline & 4 & 0,03 & & 4 & 0,07 \\
\hline & 5 & 0,05 & & 5 & 0,03 \\
\hline \multicolumn{2}{|c|}{ Rata-rata (Average) } & 0,18 & \multicolumn{2}{|c|}{ Rata-rata (Average) } & 0,17 \\
\hline
\end{tabular}

Pada Gambar 4 tampak bahwa terjadi pertambahan diameter terbesar pada pengukuran selang pertama pada kombinasi perlakuan jarak tanam $3 \mathrm{~m}$ x $3 \mathrm{~m}$ dengan dosis pupuk 2,5 ml/pohon $\left(\mathrm{J}_{2} \mathrm{~N}_{2}\right)$ sebesar $0,13 \mathrm{~cm}$, dan pada selang pengukuran kedua pertambahan diameter terbesar terdapat pada kombinasi perlakuan jarak tanam $3 \mathrm{~m}$ x $3 \mathrm{~m}$ dengan dosis pu- puk $0 \mathrm{ml} /$ pohon (kontrol) sebesar 0,10 cm.

Hasil sidik ragam yang dilakukan diketahui bahwa adanya perlakuan jarak tanam dan pemberian pupuk organik $M$ Dext memberikan pengaruh yang sangat nyata terhadap respon pertambahan diameter tanaman $D$. retusus pada tingkat kepercayaan 99\% (Tabel 10).

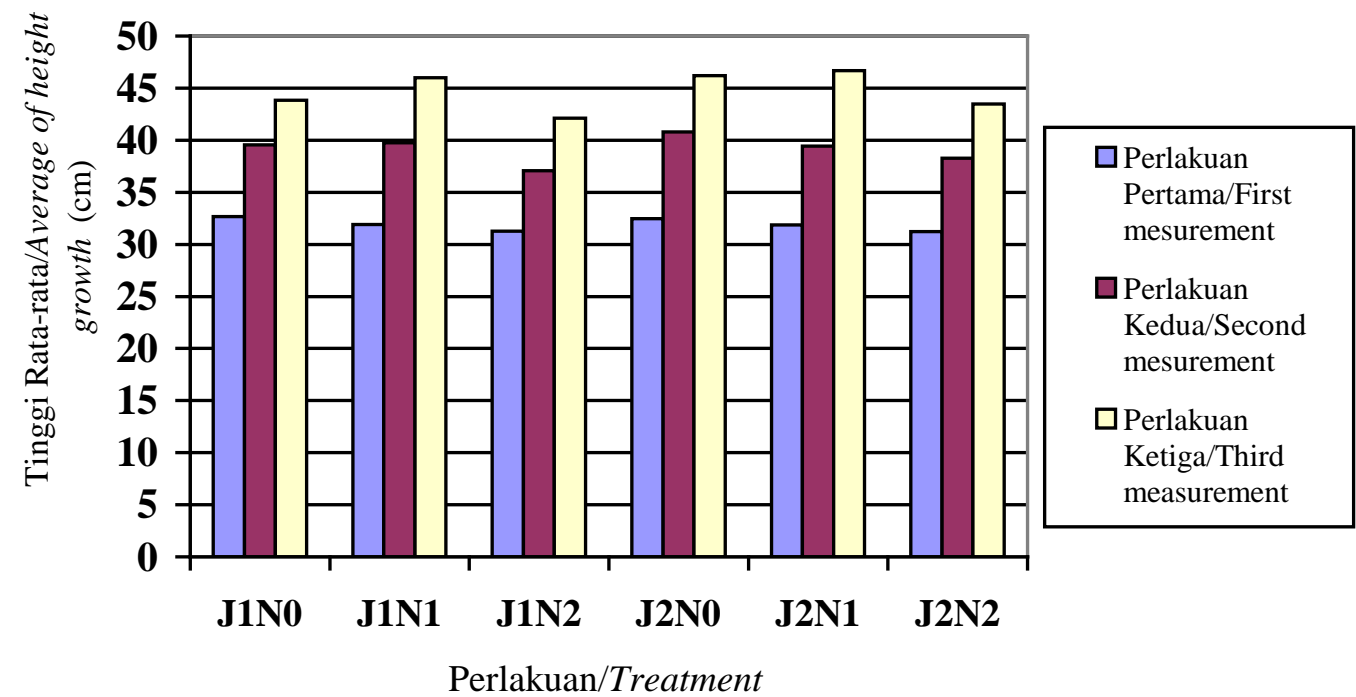

Gambar (Figure) 4. Pengaruh berbagai kombinasi perlakuan terhadap pertumbuhan diameter tanaman $D$. hasseltii (Effect of treatment combination on $\mathrm{D}$. hasseltii diameter growth) 
Tabel (Table) 10. Sidik ragam pertambahan diameter tanaman D. retusus (Analysis of variance for diameter growth rate of $\mathrm{D}$. retusus)

\begin{tabular}{lccccc}
\hline Sumber keragaman (Source of variation) & Db $(d f)$ & JK $(S S)$ & KT $(M S)$ & F & P value \\
\hline Perlakuan (Treatment) & 9 & 0,3752 & 0,0416 & $11,37 * *$ & 0,0001 \\
Galat (Error) & 20 & 0,0733 & 0,0036 & & \\
Total & 29 & 0,4485 & & & \\
\hline
\end{tabular}

** Sangat nyata pada taraf (Highly significant at level) 99\%

Tabel (Table) 11. Hasil uji lanjut pembanding linier antar perlakuan terhadap variabel diameter tanaman $D$. retusus (Result of linear test inter treatment for $\mathrm{D}$. retusus diameter growth)

\begin{tabular}{ccc}
\hline $\begin{array}{c}\text { Dosis pupuk } \\
(\text { Fertilizer dosage })(\mathrm{ml} / \text { pohon })\end{array}$ & $\begin{array}{c}\text { Jarak tanam } \\
(\text { Spacing })(\mathrm{m})\end{array}$ & $\begin{array}{c}\text { Rata-rata pertumbuhan tinggi } \\
\text { (Average of height growth })(\mathrm{cm})\end{array}$ \\
\hline 0 & 3 & 0,19 \\
0 & 5 & 0,20 \\
1 & 3 & 0,19 \\
1 & 5 & 0,17 \\
2,5 & 3 & 0,18 \\
2,5 & 5 & 0,18 \\
\hline
\end{tabular}

Hasil uji lanjut pembanding linier antar perlakuan (kontras) yang disajikan pada Tabel 11 tampak bahwa perlakuan jarak tanam $5 \mathrm{~m}$ x $5 \mathrm{~m}$ dengan dosis pupuk $0 \mathrm{ml} /$ pohon memberikan hasil terbesar pertambahan diameter sebesar $0,20 \mathrm{~cm}$ dan tanaman dengan jarak tanam $3 \mathrm{~m} \times 3$ $\mathrm{m}$ dengan dosis pupuk $1 \mathrm{ml} /$ pohon $\left(\mathrm{J}_{2} \mathrm{~N}_{1}\right)$ memberikan hasil terbaik pertambahan diameter kedua dengan pertambahan diameter sebesar 0,19 cm (Tabel 11).

\section{B. Pembahasan}

Dari hasil sidik ragam pada variabel yang diamati, secara keseluruhan adanya perlakuan jarak tanam dan pemberian pupuk organik $M$-Dext memberikan pengaruh yang berbeda terhadap respon pertumbuhan tanaman, baik pada $D$. haseltii maupun pada $D$. retusus. Namun pada umumnya perlakuan jarak tanam dan pemberian pupuk organic memberikan respon pertumbuhan yang lebih baik.

Hasil penelitian menunjukkan bahwa pemberian pupuk organik $M$-Dext pada beberapa tingkatan dosis memberikan pengaruh yang berbeda pada pertumbuhan tanaman. Hal ini berkaitan dengan ketersedian unsur hara yang dapat diserap oleh tanaman dari tanah karena adanya peng- gunaan pupuk organik M-Dext. Hadi (2001b), menyebutkan bahwa dengan adanya penggunaan pupuk organik $M$ Dext ini akan berguna untuk memperbaiki sifat fisika, kimia, dan biologi tanah, sehingga ekositem tanah menjadi selaras dan perimbangan unsur hara tanah tersedia lebih sempurna selama enam bulan dilakukan pengamatan.

Hasil yang diperoleh dari penelitian ini menunjukkan bahwa salah satu faktor yang mempengaruhi dan menentukan pertumbuhan awal tanaman adalah pemupukan. Menurut Sarief (1986), dengan adanya pemupukan akan menambah ketersediaan unsur-unsur hara yang dibutuhkan oleh tanaman untuk meningkatkan produksi dan mutu hasil tanaman. Dalam hal ini penggunaan pupuk organik selain memberikan keuntungan menambah ketersediaan unsur hara dapat pula memperbaiki struktur tanah, meningkatkan kapasitas tukar kation, menambah kemampuan tanah menahan air, dan dapat meningkatkan aktivitas biologi tanah.

Pupuk organik M-Dext adalah pupuk organik yang memiliki fungsi di antaranya adalah meningkatkan kinerja mikroba agar lebih aktif dalam menyelaraskan kesuburan tanah. 


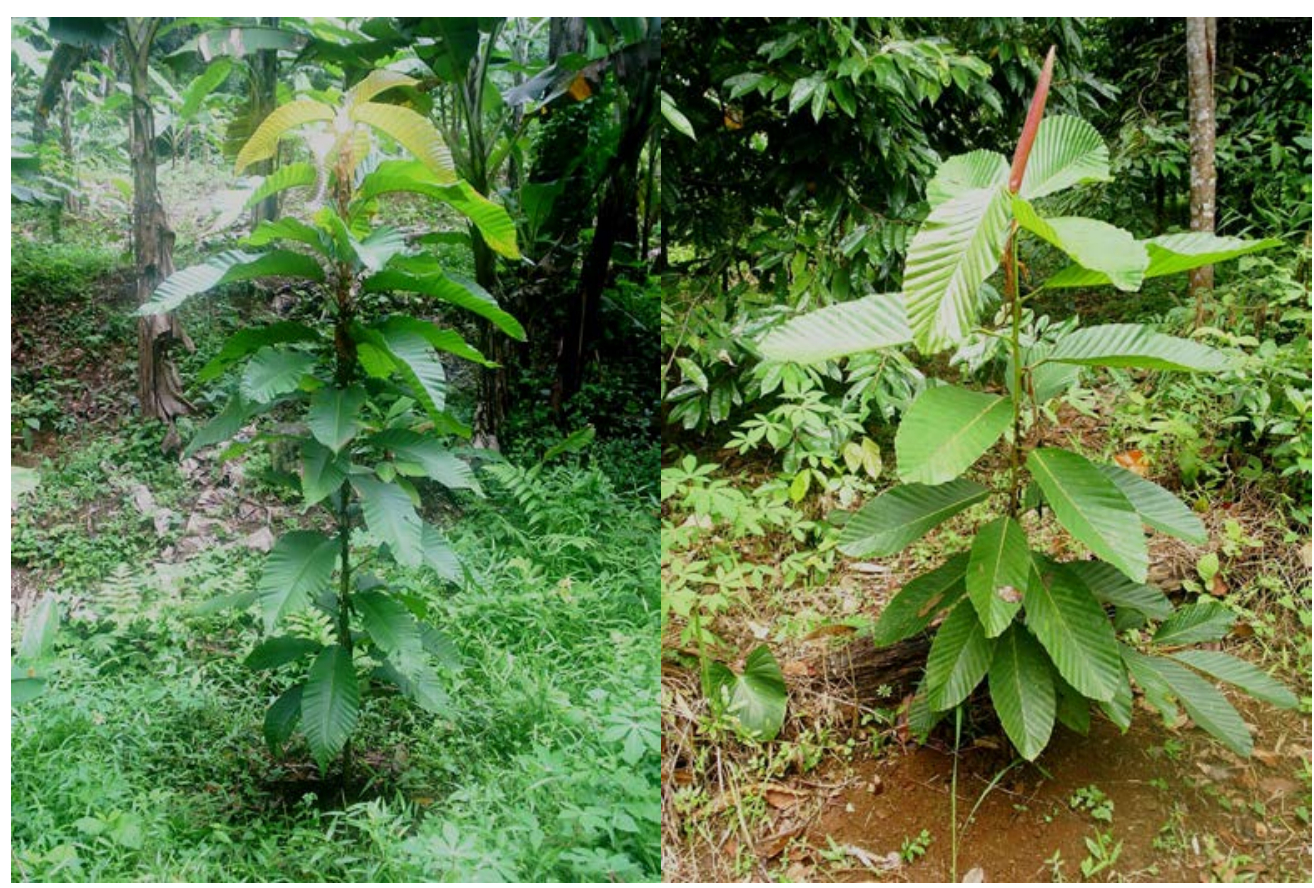

Gambar (Figure) 5. Kondisi tanaman D. hasseltii (kiri) dan D. retusus (kanan) umur satu tahun (Performance of D. hasseltii (left) and D. retusus (right) at 1 year old)

Dari penelitian ini penggunaan pupuk organik $M$-Dext dengan dosis $1 \mathrm{ml} /$ pohon memberikan pengaruh yang terbaik dibandingkan dengan kontrol dan pemberian pupuk organik $M$-Dext pada dosis 2,5 $\mathrm{ml} /$ pohon. Hal ini menunjukkan bahwa penggunaan dosis dalam pemupukan tidak dapat dilakukan sebebas-bebasnya karena ada beberapa faktor yang membatasi, antara lain adanya pengaruh pupuk terhadap sifat-sifat tanah yang merugikan dan adanya gangguan keseimbangan unsur hara di dalam tanah yang berpengaruh jelek terhadap penyerapan unsur-unsur hara tertentu oleh tanaman. Oleh karena itu penggunaaan pupuk yang terlalu berlebih belum tentu akan memberikan pengaruh yang positif terhadap pertumbuhan tanaman. Ini juga berkaitan dengan kondisi tanah di lokasi penelitian yang tergolong masam dan miskin hara, yang ditunjukkan dengan nilai $\mathrm{pH}$ yang tergolong rendah yaitu 4,6 dan kandungan N, $\mathrm{P}$, K yang juga rendah, serta adanya dominasi harendong (Melastoma malabathricum) pada tingkat tumbuhan bawah.

Selain pemupukan dan jarak tanam, salah satu faktor yang berpengaruh penting dalam pertumbuhan ini adalah kondisi lapangan, seperti kelerengan, adanya naungan, dan intensitas curah hujan yang terjadi. Tanaman palahlar seperti juga jenis tanaman dari famili Dipterocarpaceae lainnya adalah tanaman yang bersifat semi toleran yang pada saat pertumbuhan dari anakan membutuhkan naungan. Naungan ini berfungsi sebagai filter agar cahaya matahari yang diterima tanaman untuk membantu proses fotosintesis tidak terlalu banyak yang dapat membahayakan tanaman itu sendiri yaitu terjadinya kekeringan. Dalam hal ini kerapatan naungan juga sangat penting, naungan yang terlalu rapat juga akan menghambat pertumbuhan tanaman, karena proses fotosintesis yang terjadi tidak berlangsung dengan sempurna akibat kurangnya cahaya matahari. Sebaliknya, kurangnya naungan akan menyebabkan tanaman kering dan kemungkinan mati. Pada pengamatan yang dilakukan terhadap pertumbuhan tanaman palahlar ini tanaman tumbuh lebih baik pada tempat dengan kondisi naungan yang agak terbuka. 


\section{KESIMPULAN DAN SARAN}

\section{A. Kesimpulan}

1. Interaksi antara perlakuan jarak tanam dan pemberian pupuk organik $M$-Dext memberikan pengaruh yang sangat nyata terhadap pertumbuhan tinggi dan diameter tanaman Dipterocarpus retusus $\mathrm{Bl}$., sedangkan pada tanaman D. hasseltii Bl. memberikan pengaruh yang nyata pada pertumbuhan tinggi tanaman.

2. Perlakuan jarak tanam $3 \mathrm{~m} \times 3 \mathrm{~m}$ dengan dosis pupuk 1,0 ml/pohon memberikan hasil yang terbaik pada pertumbuhan rata-rata tinggi dan diameter tanaman Dipterocarpus spp. Untuk $D$. haseltii masing-masing sebesar 13,84 cm dan 0,35 cm sedangkan untuk $D$. retusus masing-masing sebesar 13,98 cm dan 0,19 cm.

3. Beberapa faktor penting yang berpengaruh dalam pertumbuhan tanaman yang menentukan dalam keberhasilan penanaman ini antara lain adalah ukuran bibit yang ditanam dan kondisi lapangan (naungan, kesuburan, kelerengan tempat, dan curah hujan).

\section{B. Saran}

Berdasarkan hasil yang diperoleh dari penelitian ini, pupuk organik $M$-Dext meningkatkan pertumbuhan anakan palahlar (Dipterocarpus spp.), terutama jenis $D$. retusus Bl. Perlu penelitian lebih lanjut terhadap penggunaan dosis pupuk organik $M$-Dext yang tepat dan disarankan interval antar dosisnya diperkecil antara 0 $\mathrm{ml} /$ pohon sampai $1 \mathrm{ml} /$ pohon.

\section{DAFTAR PUSTAKA}

Alrasyid, H. 1999. Sejarah dan Perjalanan Pembuatan Tegakan Dipterocar- paceae di Jawa. Prosiding Seminar Nasional Status Silvikultur. Yogyakarta, Agustus, 1999. Fakultas Kehutanan UGM. Yogyakarta.

Hadi, S. 2001a. Aplikasi Teknologi $M$ Dext untuk Budidaya Kedelai. Makalah Disampaikan pada Seminar dan Pelatihan Produk Teknologi Pertanian Unggulan dan Ramah Lingkungan di Bandar Lampung 56 Juni 2001.

Hadi, S. 2001b. Petunjuk Teknis Budidaya Tanaman Padi Menggunakan Teknologi M-Dext. Makalah Disampaikan pada Seminar dan Pelatihan Produk Teknologi Pertanian Unggulan dan Ramah Lingkungan di Bandar Lampung 5-6 Juni 2001.

Istomo, S. Wilarso, I. Z. Siregar. 2004. Laporan Akhir Pengembangan jenis Pohon Asli Bernilai Tinggi Palahlar (Dipterocarpus spp.) di Areal Perum Perhutani Unit III Jawa Barat dan Banten tahun 2004. Kerjasama Antara Pusat Pengembangan Sumberdaya Hutan Cepu, Perum Perhutani dengan Fakultas Kehutanan IPB.

Mattjik, A. dan I M. Sumertajaya. 2000. Perancangan Percobaan dengan Aplikasi SAS dan Minitab Jilid I. IPB Press. Bogor.

Newman, M.F., P.F. Burgess, and T.C. Whitmore 1999. Pedoman Identifikasi Pohon-Pohon Dipterocarpaceae: Jawa Sampai Niugini. PROSEA Indonesia. Bogor.

Sarief, E. S. 1986. Kesuburan dan Pemupukan Tanah Pertanian. Pustaka Buana. Jakarta.

Steel, R.G.D. and J.H. Torrie. 1980. Principles and Procedures of Statistics. McGraw-Hill, Inc. 